Eixo Roda, Belo Horizonte, v. 30, n. 4, p. 263-265, 2021

\title{
SARAIVA, Juracy Assmann; ZILBERMAN, Regina. Machado de Assis: intérprete da sociedade brasileira. Porto Alegre: Zouk, 2020.
}

\author{
Benito Petraglia \\ Universidade Federal Fluminense (UFF), Niterói, Rio de Janeiro/Brasil \\ benitop@id.uff.br \\ http://orcid.org/0000-0002-0677-5136
}

O subtítulo da coletânea de ensaios machadianos - "intérprete da sociedade brasileira" - organizada por Juracy Assmann Saraiva e Regina Zilberman faz jus ao que anuncia. Prova-nos, de modo cabal e definitivo, que Machado de Assis pode-se alinhar aos clássicos da interpretação do Brasil, como, por exemplo, Raymundo Faoro, Gilberto Freyre, Caio Prado Jr. e Sérgio Buarque de Holanda. O livro é produto do grupo de pesquisa Ficção de Machado de Assis: sistema político e contexto. É o segundo volume de ensaios organizado por elas, a partir dos trabalhos do grupo de pesquisa. O primeiro foi Machado de Assis: ficção, história e manifestações sociais.

Como disse, os ensaios provam de fato a profunda relação entre Machado de Assis e a sociedade brasileira. De resto, esta relação já nos é de algum modo fornecida pela profusão de dissertações e teses que saem dos cursos de história das universidades brasileiras.

São 21 artigos, cuja ordenação reflete as múltiplas performances do autor no mundo literário: o primeiro, de caráter mais geral, fala do gesto na ficção machadiana; os nove seguintes abordam os romances; mais quatro sobre os contos; dois sobre as crônicas; dois sobre a relação do escritor com o mundo editorial; dois sobre aspectos tradutórios da obra; e o texto final trata das primeiras manifestações literárias nos periódicos do tempo.

Romance, conto e crônica - os artigos são representativos dos gêneros literários mais longevos e nos quais o autor mais se destacou durante sua vida de operário das letras. Além disso, eles são representativos da própria feição crítica dos intérpretes de Machado. A compreensão da obra ou parte dela por um detalhe a que não se atentara: o percurso do enforcamento de um escravo em Quincas Borba como recurso para revelar a fratura estrutural da sociedade brasileira (artigo de Denise Estacio), o erro de datas em Dom Casmurro como método para mostrar que o papel do romance não é a descrição inventariante da realidade (artigo de Fernando Machado Brum); 
a comparação com obras e/ou personagens de outros escritores, no caso aqui, Erico Veríssimo (artigo de Maria da Glória Bordini); discordância entre críticos - Chalhoub versus Gledson (artigo de Sidney Chalhoub); rompimento espetacular de certo consenso crítico (Paul Dixon).

A respeito do último tópico, é notável e surpreendente a defesa que Dixon faz de Maria Olímpia, a personagem traída de "A senhora do Galvão". A crítica majoritária a esse conto assinala que Maria Olímpia compensa a traição do marido com uma exposição de "alma exterior", ao tornar-se um dos nomes da moda, literal e figurativamente falando. Dixon argumenta, porém, com um "código de honra feminino", que, suspeito, não seria muito apreciado pelas combativas feministas de hoje. E, entretanto, é um argumento-defesa passível de ser acreditado, demonstrando-se, assim, que a obra de Machado suscita e se abre a interpretações polêmicas.

Mas, por outro lado, deve-se ressaltar uma singularidade. Coletâneas sobre Machado de Assis se restringem de maneira quase absoluta à análise da obra do escritor. Nesta, dois artigos tratam da relação de Machado com o mundo editorial. O primeiro, de Lúcia Granja, leva justamente o título de "Machado de Assis: relações com o mundo editorial". A autora destaca basicamente o envolvimento do escritor com as atividades editoriais dos irmãos Garnier, sobretudo o caçula Baptiste-Louis Garnier, com quem lidou aqui no Brasil na edição de seus livros.

O outro é de Regina Zilberman - "Machado de Assis e a poesia de Faustino Xavier de Novaes". O ensaio traz uma notícia desconhecida, quem sabe, não asseguro, até para os machadianos mais pertinazes, e dizer machadiano pertinaz é quase perpetrar um pleonasmo vicioso. Machado de Assis organizou, em 1870, um volume de poemas de Faustino Xavier de Novaes, cunhado póstumo de Machado, chamado Poesias póstumas. Segundo Regina Zilberman (2020, p. 236-237), “as Poesias póstumas constituem provavelmente a única obra em que teria atuado em todas as etapas de uma produção editorial, desde a coleta do material até o lançamento do livro pronto."

Seria natural que numa coletânea o resenhista manifestasse predileção por um ou outro artigo. E se é certo que preferências são regidas por critérios pessoais, creio haver dados objetivos que justifiquem a simpatia por dois deles.

O primeiro - "O gesto na ficção machadiana" (Kenneth David Jackson) -, primeiro também do livro, traz a novidade da sistematização de um procedimento na ficção machadiana. Ele nos faz compreender, numa espécie de "insight", que a expressividade e a plasticidade da frase machadiana se traduzem por uma segunda linguagem, pela sugestão de uma camada "invisível", que é a linguagem do gesto, "relacionada à consciência 
e ao entendimento do mundo, num plano maior, invocando inclusive o mistério do mundo e da experiência humana" (p. 15).

Vale a pena citar outra passagem: "Na ficção de Machado de Assis, o gesto ocupa uma posição de destaque, tanto que a leitura equivale à assistência a uma performance de cenas teatrais, encenadas pelos personagens no palco de um grande teatro do mundo" (p.15). É quase impossível que os leitores de Machado não se reportem a "Missa do Galo", àquele jogo cênico que representam os movimentos de Conceição em volta do jovem Nogueira.

O segundo ensaio - "O teatro da vida: a ópera em Dom Casmurro" (Débora Bender) - segue pelo terreno já pisado da comparação entre a ópera, tal como concebida pelo personagem Marcolini, e a trama de Dom Casmurro. Mas ele é vazado naquela simplicidade difícil que faz fluir o texto de modo espontâneo e natural, num didatismo que esclarece e, ao mesmo tempo, torna mais profunda a correlação.

Ela começa por conceituar o gênero, sua origem e sua significação cultural. A relação com Dom Casmurro é feita primeiro atribuindo-se a cada personagem o papel que teria na ópera: Bento Santiago - tenor; Capitu soprano; Escobar - baixo; D. Glória - contralto; José Dias - barítono; Pádua, Padre Cabral, Tio Cosme, prima Justina, Sancha e Fortunata - comprimários compondo o coro. Distribuídos os papéis, vem o sentido da representação: "o libreto escrito por Deus, o impacto da música de Satanás e a falta de harmonia entre os dois, libreto e partitura, mudam o roteiro, e a dissonância do ciúme inunda o drama e age sobre as personagens, trazendo adversidade e desgostos" (p. 106).

A seguir, refere-se às diferentes interpretações que a metáfora da ópera recebeu dos críticos Helen Caldwell, Eugênio Gomes, John Gledson e Abel Barros Baptista. A conclusão é que "com a metáfora da ópera, Machado de Assis discute questões morais do ser humano, como a falsidade, a dissimulação, o exagero, a mentira, atributos essenciais aos homens em suas representações" (p. 106). Não, o leitor não pode se sentir roubado com a antecipação deste breve resumo e mais as citações. A singeleza e a pertinência do texto estão lá intactas esperando por ele.

É profícua a leitura dos ensaios. Dá-nos uma ampla visão do percurso do nosso maior escritor. Prova-nos que Machado e Brasil são termos de uma igualdade. Prova-nos talvez mais - que ele ultrapassou o estágio da nacionalidade e alcançou a universalidade da marca humana, como Shakespeare ou Cervantes, dixit Harold Bloom, dixit Carlos Fuentes.

Recebido em: 11 de fevereiro de 2021.

Aprovado em: 30 de agosto de 2021. 